\title{
턱관절과 넙다리뒤근 교유수용성신경근촉진 중재가 능동 입벌리기 및 넙다리뒤근 유연성에 미치는 영향
}

\author{
윤삼원 ${ }^{1}$, 손호희 ${ }^{2}$ \\ ${ }^{1}$ 부산가톨릭대학교 보건과학대학 물리치료학과 대학원 \\ ${ }^{*}$ 부산가톨릭대학교 보건과학대학 물리치료학과
}

The Effects of Proprioceptive Neuromuscular Facilitation(PNF) Intervention for Temporomandibular Joints and Hamstring on Active Mouth Opening and Hamstring Flexibility

\author{
Sam-Won Yun ${ }^{1}$, Ho-Hee Son ${ }^{* 2}$ \\ ${ }^{1}$ Catholic University of Pusan, College of Health Sciences, Department of Physical Therapy \\ ${ }^{* 2}$ Catholic University of Pusan, College of Health Sciences, Department of Physical Therapy
}

\begin{abstract}
Purpose The purpose of this study was to investigate the effects of proprioceptive neuromuscular facilitation(PNF) intervention for temporomandibular joints and hamstring on active mouth opening and hamstring flexibility. Methods 17 healthy adults were included in this randomized, single blind, crossover design study. The possibility of carry over effect could not be excluded. Before and after intervention, forward flexion distance, popliteal angle and active mouth opening were evaluated and results were analyzed. After first participating in the proprioceptive neuromuscular facilitation(PNF) intervention for temporomandibular joints, each subject visited again after a week to prevent the carry-over effect and then participate in the other intervention. Results Both proprioceptive neuromuscular facilitation(PNF) intervention significantly improved forward flexion distance, popliteal angle and active mouth opening. Comparing the two intervention, TM joint intervention significantly improved popliteal angle. Hamstring intervention significantly improved active mouth opening. No significant differences in forward flexion distance test were found between interventions. Conclusion Although proprioceptive neuromuscular facilitation(PNF) intervention on hamstring had a effect on indirect intervention of active mouth opening, it is considered that more study is needed for clinical application.
\end{abstract}

Key words Proprioceptive Neuromuscular Facilitation, Active Mouth Opening, Hamstring, Direct, Indirect

Corresponding author Son hohee(sonhh@cup.ac.kr)

Received date 4 April 2017

Revised date 8 May 2017

Accepted date 19 June 2017

\section{I. 서 론}

턱관절은 지속적으로 가장 많이 사용되는 인체 관절 가운데 하 나로서 씹기, 삼키기뿐만 아니라 말하는 과정에서도 사용되며 하루 2,000회 이상 움직이며 약 3.5톤의 압력을 치아 조직에 가하게 된다. ${ }^{1)}$ 국내에서는 턱관절의 장애로 인하여 병원을 찾 는 평균 환자 수는 전체 인구의 $0.15 \%$ 였고 3 년간 매년 증가하 는 추세를 보인다고 하였다. ${ }^{2)}$ 그리고 Zhang 등 $(2015)^{3)}$ 은 스 웨덴, 영국, 홍콩, 스페인, 캐나다 그리고 미국 인구 중 약

doi : http:dx.doi.org/10.17817/2017.04.12.111113
5\% 12\%가 턱관절 장애를 않고 있으며 가장 흔히 발생하는 근골격계 질환 중 두 번째에 해당한다고 보고하였다.

턱관절의 장애가 발생할 시 나타나는 증상으로는 아래턱의 운동과 관련된 불쾌감, 관련 근육들의 통증과 피로로 인한 씹 기시 장애, 턱관절 운동시 관절에서 발생되는 관절잡음 그리고 입벌리기의 제한이 있다. 이 중에 턱관절 장애의 3대 증상은 턱관절의 부조화, 아래턱 운동시 턱의 통증 그리고 입벌리기 제한이다. ${ }^{4)}$ 입벌리기 제한의 치료로는 턱교정 수술 등의 비가 역적인 치료와 약물요법과 물리치료 등의 가역적인 치료방법이 있다. 이 중에서 보존적이고 가역적인 치료가 우선적으로 시행 되고 있으며 비가역적인 치료는 가급적 최소로 시행되고 있 다. ${ }^{5),(6)}$ 보존적 요법인 약물요법 중에서는 진통제, 근육이완제,

This paper was supported by the research grant of the Catholic University of Pusan in 2016 
삼환계 항우울제 등이 턱관절 장애의 통증에 효과가 있다는 연 구가 많이 있으나 이러한 약물의 유용함에도 불구하고, 약물 중독, 이전 약들과의 상충 혹은 부작용 등과 같은 문제가 발생 할 수도 있다. ${ }^{7}$ 그에 비해 물리치료 요법은 가역적이며 부작용 도 적을 뿐만 아니라 비용도 적게 드는 장점이 있다. 입벌리기 제한을 치료하기 위한 물리치료로는 물리적 인자 요법, 도수치 료 그리고 고유수용성신경근촉진 치료 등이 있다. ${ }^{8), 9)}$ Bumann 등 $(2002)^{10)}$ 은 도수치료는 씹기 장애를 치료하기 위해서 물리 치료사들이 사용하는 필수적인 치료법이라 하였으며, 도수치료 를 통하여 관절낭의 운동성이 증가될 뿐만 아니라 짧아진 근육 을 신장시키거나 약해진 근육을 강화시킬 수 있다. ${ }^{11-13)}$

그러나 관절이 불안정하고 운동성이 저하되어 있을 때에는 내재성 관절움직임을 유발하기 위한 도수치료의 사용을 하지 말아야 한다. 과도한 내재성 관절 움직임을 유발하기 위한 도 수치료는 관절내의 불안정성을 증가시킬 수 있으므로 우선 고 유감각과 운동감각을 향상시킬 수 있는 고유수용성신경근촉진 중재를 점진적으로 사용하는 것이 좋다. ${ }^{14)}$ 고유수용성신경근촉 진 중재는 신경생리학적인 기전을 통해 관절의 움직임까지 크 게 향상될 수 있다고 한다. 고유수용성신경근촉진 중재에서 작 용근의 수축은 상호억제를 거쳐 대항근의 이완을 이끌어 낸다. 그래서 입벌리기 동작의 작용근에 치료를 적용하면 대항근의 이완이 유발되어 입벌리기 범위가 증가될 수 있다. 또한, 작용 근의 수축을 7 10초로 지속할 시 움직임의 범위가 가장 증가 하였다는 연구도 있었다. ${ }^{15)}$

위의 물리적 인자 요법과 도수치료 그리고 고유수용성신경근촉진 중재는 병터의 직접적인 적용이 많다. 그러나 Espejo 등(2016) ${ }^{9)}$ 은 턱관절과 멀리 떨어진 넙다리뒤근의 고유수용성신경근촉진 중재를 적 용 시 넙다리뒤근의 유연성 뿐만 아니라 능동 입벌리기의 범위가 증가 할 수 있다고 하였다. 만약 병터의 통증이 극심하여 직접적인 중재를 적용하기에 어려움이 따를 경우 Espejo 등(2016) ${ }^{9)}$ 의 연구와 같이 병 터가 아닌 떨어진 부위의 중재를 통해 원하는 치료효과를 얻을 수 있 을 것으로 사료된다. 이처럼 통증부위에 직접 적용하는 중재가 아닌 원격부위의 중재를 통해 치료효과를 간접적으로 얻을 수 있다면 임상 적으로 많은 가치가 있을 것이다.

비록 선행연구에서 넙다리뒤근과 같이 먼 부위의 고유수용성신경 근촉진 중재가 어느 정도 효과가 있다고 하였지만 이 간접적인 중재가 실제 임상에 통용되기 위해서는 직접적인 중재와 비교한 연구가 필요 하다고 사료되는데 아직 이러한 연구가 부족한 실정이다. 이에 본 연 구에서는 턱관절과 넙다리뒤근의 고유수용성신경근촉진 중재가 능동 입벌리기 범위의 변화량과 넙다리뒤근 유연성의 변화량에 미치는 영향 을 알아보고자 한다.

\section{II. 연구방법}

\section{1. 연구 대상자}

본 연구의 대상자들은 부산광역시에 살고 있는 20 30대 성인 남녀 중에서 연구의 목적과 방법을 충분히 이해하고 자발적으 로 참여 동의 의사를 밝힌 17 명을 대상으로 하였다.

대상자는 연구자의 지시를 따르는데 문제가 없으며, 연구의 운동 을 진행하기에 충분한 근력을 가지고 있으며, 운동 범위 내에서 관절 범위의 제한을 가지지 않는 이들로 선정하였다. 최근 6 개월간 급성 허 리통증을 경험한 자, 과거 목뼈의 채찍질 손상을 경험한 자, 신경정신 과적 문제가 있는 자는 본 연구의 선정과정에서 제외되었다. 본 연구 는 부산가톨릭대학교 연구윤리위원회의 심의를 받아 진행되었다.

\section{2. 연구 설계}

본 연구는 교차설계(cross-over trial) 연구방법을 사용하였다. 초기 평가 후 대상자들은 두 가지 중재방법에 무작위로 배치하 였으며 각 중재에 참여한 다음 이월효과를 막기 위해 1 주일이 지난 후 재 방문하여 두 번째 중재에 참여하였다. ${ }^{16)}$ 본 연구의 중재는 대한고유수용성신경근촉진법 자격증을 보유하고 있으며 숙달되어 있는 물리치료사 1 명에 의해 실시되었다.

\section{3. 측정 방법}

모든 대상자들은 각 중재의 전과 후에 앞으로 숙이기 검사, 오 금 각 검사 그리고 능동 입벌리기 검사를 실시하였다.

\section{1) 앞으로 숙이기 검사forward flexion distance test)} 대상자는 넙다리뒤근 유연성 측정 박스 위에 바른 자세로 선 다. 무릎관절은 곧게 편 상태를 유지하면서 상체를 앞으로 최 대한 숙인다. 손가락을 쪽 편 상태로 두 팔을 최대한 내린 후 지면과 가운데손가락과의 거리를 3 회 측정하여 평균값을 측정 치로 하였다.

\section{2) 오금 각 검사(popliteal angle test)}

대상자는 바로 누운 자세를 취한다. 검사 측 아래다리의 엉덩 관절과 무릎관절을 $90^{\circ}$ 로 위치시킨다. 이 자세에서 넙다리뼈의 가쪽융기에 각도기의 축을 일치시키고 대상자에게 무릎관절을 최대한 펴도록 지시한 후 오금 각을 3회 측정하여 평균값을 측 정치로 하였다. 이때, 골반의 움직임과 엉덩관절의 움직임이 일 어나지 않도록 한다.

\section{3) 능동 입벌리기 검사(active mouth opening)}

대상자는 목뼈를 중립자세로 위치시킨 후 바로 누운 자세를 취 한다. 무릎을 살짝 굽히고 두 팔은 몸통 옆에 가지런히 놓은 자세에서 통증이 없는 최대 범위의 능동 입벌리기시 윗니와 아 


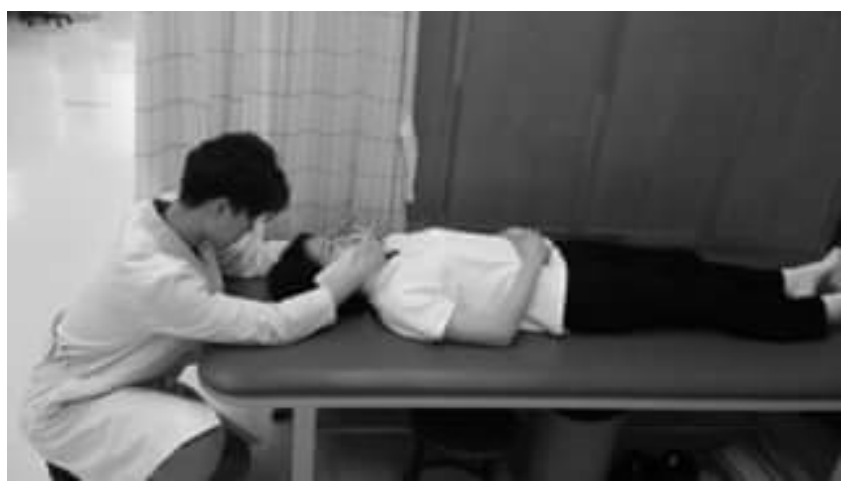

Figure 1. Proprioceptive neuromuscular facilitation for temporomandibular joint

랫니의 정중열사이의 간격으로 하여 그 거리를 $1 \mathrm{~mm}$ 민감도를 가지고 있는 눈금자를 이용하여 최대 입벌리기 범위를 3회 측 정하였고, 그 평균값을 측정치로 하였다.

\section{4. 중재 방법}

1) 턱관절 고유수용성신경근촉진 중재

치료사는 대상자의 아래턱에 손바닥을 촉지한 후 입벌리기에 대하여 등척성 저항을 8초간 가한다. 대상자들은 치료사 손의 저항에 대항하여 8초간 등척성 입벌리기 운동을 실시한다.

그리고 나서 대상자는 근 수축이 일어나지 않게 눈을 감고 턱관절을 8 초간 이완시킨다. ${ }^{17)} 8$ 초간 등척성 입벌리기 운동과 8 초간 이완을 1 세트로 하여 3 세트를 총 48 초 $(8$ 초 수축 +8 초 이완 +8 초 수축 +8 초 이완 +8 초 수축 +8 초 이완 $)$ 정도 간 실시하였다.

\section{2) 넙다리뒤근 고유수용성신경근촉진 중재}

대상자는 침대 위에 바로 누운 자세를 취하고 중재 반대 측 아 래다리에 골반과 허벅지 부위를 스트랩(strap)으로 고정시킨다. 무릎을 폄(extension) 상태에서 대상자의 넙다리뒤근이 신장 될 때 통증을 최대로 참을 수 있는 범위까지 수동으로 엉덩관 절을 굽힘시킨다. ${ }^{18)}$ 이 상태에서 넙다리뒤근이 수축할 수 있게 무릎을 굽히면서 엉덩관절을 8초간 폄 시키며 이때, 치료사는 저항을 가한다. ${ }^{19)}$ 수축이 완료되면 처음 자세로 돌아와서 8초 동안 근 수축이 일어나지 않게 눈을 감고 이완한다. 8초간 수

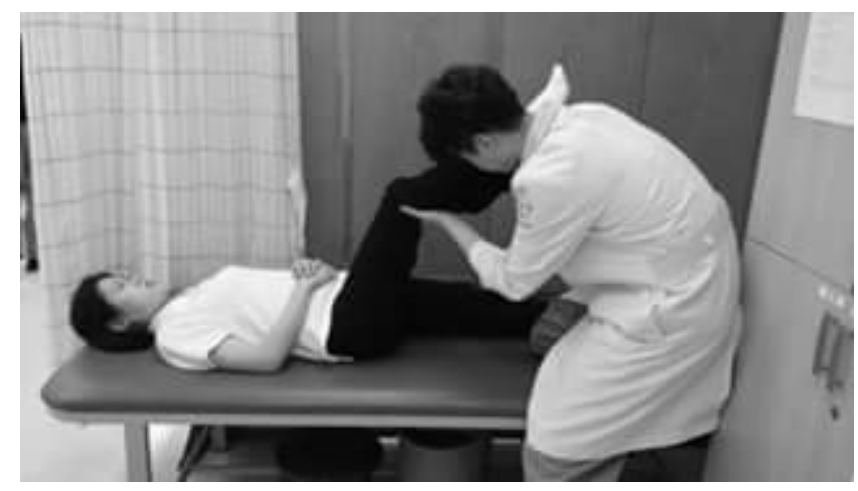

Figure 2. Proprioceptive neuromuscular facilitation for hamstring muscle

축운동과 8 초간 이완을 1 세트로 하여 3 세트를 총 48 초 $(8$ 초 수 축 +8 초 이완 +8 초 수축 +8 초 이완 +8 초 수축 +8 초 이 완) 정도 간 실시하였다.

\section{5. 분석방법}

본 연구의 자료는 SPSS 21.0 ver for windows를 이용하여 통계 처리를 하였고 유의수준은 0.05 로 설정하였다. 각 중재 전과 후에 따른 능동 입벌리기 범위와 넙다리뒤근 유연성의 변 화량을 알아보기 위해 대응 표본 t검정(paired t-test)을 실시 하였으며, 두 중재 별 변화량을 비교하기 위해 독립 표본 $\mathrm{t}$ 검정 (independent t-test)을 실시하였다.

\section{III. 결 과}

\section{1. 대상자의 일반적 특성}

본 연구에 참여한 대상자는 총 17 명(남자 10 명, 여자 7 명)의 성인 남녀이며, 평균 연령은 22.35세이며, 평균 키는 $170.11 \mathrm{~cm}$, 평균 몸무게는 $64.52 \mathrm{~kg}$ 이었다<Table $1>$.

\section{2. 사전 동질성 검정}

중재 전 앞으로 숙이기 검사, 오금 각 검사 그리고 능동 입벌 리기 검사에서 집단간 유의한 차이를 보이지 않았다.

Table 1. Demographic characteristics of the subjects $(n=17)$

\begin{tabular}{cc} 
Variable & Total \\
Gender(male/female) & $10 / 7$ \\
Age(year) & $22.35 \pm 2.84$ \\
Height $(\mathrm{cm})$ & $170.11 \pm 6.20$ \\
Weigh $(\mathrm{kg})$ & $64.52 \pm 7.89$ \\
\hline
\end{tabular}

Mean \pm standard deviation; ${ }^{*} \mathrm{p}<.05$ 


\section{3. 턱관절 고유수용성신경근촉진 중재}

턱관절 고유수용성신경근촉진 중재 시 앞으로 숙이기 검사, 오 금 각 검사 그리고 능동 입벌리기 검사에서 모두 통계적으로 유의한 차이가 있었다 $(\mathrm{p}<0.05)<$ Table $3>$.

\section{4. 넙다리뒤근 고유수용성신경근촉진 중재}

넙다리뒤근 고유수용성신경근촉진 중재 시 앞으로 숙이기 검 사, 오금 각 검사 그리고 능동 입벌리기 검사에서 모두 통계적 으로 유의한 차이가 있었다 $(\mathrm{p}<0.05)<$ Table $4>$.

\section{5. 그룹 간 각 검사의 변화량 비교}

그룹 간 각 검사의 변화량을 비교한 결과 앞으로 숙이기 검사 에서는 유의한 차이가 없었고 오금 각 검사와 능동 입벌리기 검사에서는 유의한 차이가 있었다<Table 5>.

\section{IV. 고 찰}

본 연구는 턱관절 고유수용성신경근촉진 중재와 넙다리뒤근 고 유수용성신경근촉진 중재 후 능동 입벌리기와 앞으로 숙이기 그리고 오금 각 범위에 미치는 영향을 비교하고자 17 명의 건 강한 20대 성인 남녀에게 교차설계(cross-over trial)방법을 이용하여 연구하였다.

턱관절의 고유수용성신경근촉진 중재와 넙다리뒤근 고유수 용성신경근촉진 중재를 적용한 결과 앞으로 숙이기 검사와 오 금 각 검사 그리고 능동 입벌리기 검사에서 두 군 모두 유의하 게 증가하였다. 각 그룹간 변화량의 비교에서 앞으로 숙이기 검사에서는 두 군간의 유의한 차이는 없었고 오금 각 검사와 능동 입벌리기 검사에서는 턱관절에 직접 중재를 적용한 그룹 의 변화량이 유의하게 크게 나타났다.

Table 2. Comparisons of forward flexion distance, popliteal angle, active mouth opening in TMJ group

\begin{tabular}{ccccc} 
Variables & TI & HI & t & p \\
Forward flexion distance test $(\mathrm{cm})$ & $2.69 \pm 7.89$ & $2.48 \pm 8.19$ & -0.10 & 0.92 \\
Popliteal angle test $\left({ }^{\circ}\right)$ & $65.82 \pm 9.11$ & $65.47 \pm 8.79$ & 0.59 & 0.56 \\
Active mouth opening $(\mathrm{cm})$ & $4.39 \pm 0.46$ & $4.73 \pm 0.47$ & -9.11 & 0.37 \\
\hline
\end{tabular}

Mean \pm standard deviation; ${ }^{*} \mathrm{p}<.05$; tempromandibular joint intervention, $\mathrm{TI}$; Hamstring intervention, $\mathrm{HI}$

Table 3. Comparisons of forward flexion distance, popliteal angle, active mouth opening in TMJ group

\begin{tabular}{ccccc} 
variables & Pre & Post & t & p \\
Forward flexion distance test $(\mathrm{cm})$ & $2.69 \pm 7.89$ & $0.35 \pm 7.49$ & 6.97 & $<0.01^{*}$ \\
Popliteal angle test $\left({ }^{\circ}\right)$ & $65.82 \pm 9.11$ & $68.05 \pm 8.86$ & -4.88 & $<0.01^{*}$ \\
Active mouth opening $(\mathrm{cm})$ & $4.39 \pm 0.46$ & $4.73 \pm 0.47$ & -9.11 & $<0.01^{*}$ \\
\hline
\end{tabular}

Mean \pm standard deviation; ${ }^{*} \mathrm{p}<.05$;

Table 4. Comparisons of forward flexion distance, popliteal angle, active mouth opening in Hamstring group

\begin{tabular}{ccccc} 
variables & Pre & Post & t & p \\
Forward flexion distance test $(\mathrm{cm})$ & $2.47 \pm 8.19$ & $-0.35 \pm 7.83$ & 8.14 & $<0.01^{*}$ \\
Popliteal angle test $\left({ }^{\circ}\right)$ & $65.47 \pm 8.79$ & $70.82 \pm 9.22$ & -6.15 & $<0.01^{*}$ \\
Active mouth opening $(\mathrm{cm})$ & 4.42 & 4.6 & -3.46 & $<0.01^{*}$ \\
\hline
\end{tabular}

Mean \pm standard deviation; ${ }^{*} p<.05$;

Table 5. Comparison of pre-post changes between groups

\begin{tabular}{cccccc}
\hline variables & TI & HI & t & p \\
Forward flexion distance test $(\mathrm{cm})$ & $2.34 \pm 1.38$ & $2.83 \pm 1.44$ & -1.02 & 0.31 \\
Popliteal angle test $\left({ }^{\circ}\right)$ & $2.23 \pm 1.89$ & $5.35 \pm 3.59$ & 3.17 & $<0.01^{*}$ \\
Active mouth opening $\left(\mathrm{c}^{\prime} \mathrm{m}\right)$ & $0.34 \pm 0.15$ & $0.14 \pm 0.15$ & -3.88 & $<0.01^{*}$ \\
\hline
\end{tabular}

Mean \pm standard deviation; ${ }^{*} \mathrm{p}<.05$; tempromandibular joint intervention, $\mathrm{TI}$; Hamstring intervention, $\mathrm{HI}$ 
본 연구에서는 고유수용성신경근촉진 중재에서 유지 후 이 완(Hold-Relax) 기법을 적용하였다. 그 이유로는 많은 넙다리 뒤근 신장 기법 중에서도 유지 후 이완 기법을 사용한 넙다리 뒤근 고유수용성신경근촉진 중재가 가장 흔하게 사용되고 있으 며 뿐만 아니라 관련된 연구도 많이 이루어져 왔기 때문이 다. ${ }^{19-21)}$ Youdas 등 $(2010)^{21)}$ 은 넙다리뒤근 고유수용성신경근 촉진 중재가 어떤 넙다리뒤근 신장 기법 보다 더 효과적이라고 하였는데 그 이유는 골지힘줄기관과 근방추를 통해 이뤄지는 신경생리학적인 기전으로 인해 관절가동범위가 증가되기 때문 이라고 하였다. 위의 신경생리학적인 기전은 전통적으로 골지 힘줄기관의 장력 수용기를 거치는 자가억제기전과 근방추를 거 치는 상호 억제기전을 포함하며, 이를 통해 넙다리뒤근의 억제 가 유발된다. 뿐만 아니라 $\operatorname{Lim}$ 등 $(2014)^{19)}$ 은 고유수용성신경 근촉진 중재는 근 수축을 유발하는 반사활동을 감소시키기 위 해 신장 전에 자발적인 근 수축을 시행 하여 근 이완을 유발한 다고 하였으며 이러한 이유로 Espejo 등(2016) ${ }^{9}$ 의 연구에서 능동 입벌리기의 간접적인 치료로 넙다리뒤근 고유수용성신경 근촉진 중재를 적용하였다.

턱관절의 직접적인 중재에 해당하는 턱관절 고유수용성신 경근촉진 중재를 적용한 후 앞으로 숙이기 검사와 오금 각 검 사 그리고 능동 입벌리기 범위에서 유의하게 증가하였다. 이는 깨물근의 근막 통증유발점에 의해 야기된 턱관절 장애의 치료 인 초음파치료와 고유수용성신경근촉진 중재효과에 대해 비교 한 $\mathrm{Gray}(2002)^{22)}$ 의 연구에서 턱관절에 5 분간 초음파 치료를 받은 군에서는 능동 입벌리기에서 유의한 차이가 없었으나, 턱 관절에 고유수용성신경근촉진 중재를 받은 군에서는 능동 입벌 리기에서 유의하게 증가한 양상을 보였다는 결과와 일치하는 경향을 보였다.

턱관절의 간접적인 중재에 해당하는 넙다리뒤근 고유수용 성신경근촉진 중재의 적용 후 앞으로 숙이기 검사와 오금 각 검사 그리고 능동 입벌리기 범위가 유의하게 증가하였고 이는 턱관절 장애가 있는 운동선수를 넙다리뒤근 신장만을 적용한 실험군 혹은 깨물근의 허혈성 압박 마사지와 넙다리뒤근 신장 을 결합하여 적용한 대조군으로 나누어 넙다리뒤근 유연성과 능동 입벌리기 그리고 통증의 즉각적인 변화를 알아본 Espejo 등 (2016) $)^{9)}$ 의 연구에서 실험군 뿐만 아니라 대조군 모두에서 능동 입벌리기가 유의하게 증가하였다는 결과와 일치하는 경향 을 보였다.

이처럼 원격부위의 중재를 적용하여 턱관절에 간접적인 효 과를 알아보는 연구는 꾸준히 있어왔다. 깨물근의 통증유발점 이 있다고 진단받은 성인 남녀에게 넙다리뒤근 신장 기법 적용 후 즉각적인 효과에 대하여 알아본 Fernández 등 $(2005)^{23)}$ 의 연구에서 넙다리뒤근 근 에너지기법을 적용하였을 시 깨물근의 통증이 줄어들며 능동 입벌리기가 증가한다고 하였고, 건강한
성인 남, 녀에게 넙다리뒤근 신장 기법 적용 후 즉각적인 효과 에 대하여 알아본 Bretischwerdt 등 $(2010)^{24)}$ 의 연구에서는 양쪽 넙다리뒤근 혹은 우세발의 넙다리뒤근에 정적 신장을 적 용하였을 시 위 등세모근과 깨물근에서 통증이 감소하였고 능 동 입벌리기가 증가하였다는 연구 내용으로 미루어 보아 고유 수용성신경근촉진 중재를 통한 넙다리뒤근의 신장과 능동 입벌 리기 상호간에 밀접한 관계가 있음을 알 수 있었다.

그러나 턱관절과 넙다리뒤근 고유수용성신경근촉진 중재 후 각각의 넙다리뒤근 유연성과 능동 입벌리기 변화량을 비교한 결 과 앞으로 숙이기 검사에서는 두 중재군 모두 효과는 있었지만 서로 간의 유의한 차이가 없었고, 오금 각 검사에서는 두 중재 군 모두 효과는 있었지만 직접적인 중재에 해당하는 넙다리뒤근 고유수용성신경근촉진 중재군이 더 유의하게 증가하였다. 능동 입벌리기 검사에서도 두 중재군 모두 효과는 있었지만 직접적인 중재에 해당하는 턱관절 고유수용성신경근촉진 중재군이 더 유 의하게 증가하였다. 넙다리뒤근 유연성에 대한 검사인 앞으로 숙이기 검사와 오금 각 검사에서 서로 다른 결과가 나온 이유는 양쪽 모두의 턱관절에 중재를 적용한 것에 반해 한 다리의 넙다 리뒤근만 중재를 적용하였기 때문이라고 사료된다. 능동 입벌리 기 검사를 보면 직접적인 중재에 해당하는 턱관절 고유수용성신 경근촉진 중재에서 유의하게 증가하였는데 턱관절의 좌상-역좌 상 기법과 신경근 테크닉에 따른 능동 입벌리기의 변화에 관하 여 연구한 Jordi 등 $(2008)^{25)}$ 에 따르면 각각 능동 입벌리기가 $0.4 \mathrm{~cm}$ 만큼 유의하게 증가하였고, 턱관절 고유수용성신경근촉진 중재를 적용한 $\mathrm{Gray}(2002)^{17)}$ 의 연구에서는 2 번째 방문에서 능 동 입벌리기가 $0.28 \mathrm{~cm}$ 증가하였고, 4 번째 방문에서는 $0.66 \mathrm{~cm}$ 까지 증가하였다. 이에 반해 건강한 성인을 대상으로 넙다리뒤 근 신장기법을 적용한 Bretischwerdt 등 $(2010)^{24)}$ 의 연구에서 는 우세쪽 넙다리뒤근 신장기법 적용 후 능동 입벌리기가 $0.08 \mathrm{~cm}$ 증가하였고, Espejo 등 $(2016)^{9)}$ 의 연구에서는 넙다리 뒤근 고유수용성신경근촉진 중재 적용 후 $0.34 \mathrm{~cm}$ 증가하였다. 본 연구 결과에서도 넙다리뒤근 고유수용성신경근촉진 중재 시 능동 입벌리기가 $0.14 \mathrm{~cm}$ 증가하였는데 반해 턱관절 고유수용 성신경근촉진 중재 시 $0.34 \mathrm{~cm}$ 증가한 것으로 나타나 넙다리뒤 근의 고유수용성신경근촉진 중재를 포함한 간접적인 신장중재에 비해 직접적인 턱관절 중재 그룹에서 능동 입벌리기 증가량이 크게 나타났다.

본 연구의 결과를 통해 턱관절과 넙다리뒤근 고유수용성신 경근촉진 중재가 능동 입벌리기와 넙다리뒤근 유연성에 간접적 인 영향을 미치는 것을 알 수 있었다. 그 이유는 아마도 턱관 절과 위 목뼈 그리고 넙다리뒤근 간의 밀접한 관계가 있기 때 문인 것으로 사료된다. Natalia 등 $(2010)^{26)}$ 의 연구에 따르면 위 목뼈와 턱관절 상호 간 생체역학적인 관련성이 있다고 하였 고, Taylor 등 $(2003)^{27)}$ 은 위 목뼈의 등척성 수축 후 이완시 
경막이 신장되어 넙다리뒤근과 같은 다른 부위에 원격치료의 효과를 이끌어 낼 수 있다고 하였다. 뿐만 아니라 Cho 등 $(2014)^{28)}$ 은 뒤통수밑근의 이완으로 인해 표면후방선이 이완 되어 넙다리뒤근 유연성에 영향을 미칠 수도 있다 하였고, 뒤 통수밑근은 머리 자세의 조정에 상당히 기여하며, 인체에서 가 장 많은 근 방추를 가지고 있는 고유수용성감각 감지기라고 하 였다. Pollard 등 $(1997)^{29)}$ 은 목뼈는 아래다리와 팔의 기능과 자세조절에 중요한 역할을 한다고 하였다. 그들은 뒤통수밑근 에 고유수용성신경근촉진 중재를 적용 시 그 결과로 활성화된 고유수용성감각 정보가 자세긴장도(posture tone)를 바꿀 수 있으며, 이 고유수용성감각 정보는 대뇌겉질과 위둔덕, 전정핵, 그물체 그리고 소뇌겉질을 거쳐 전정척수로, 그물척수로 그리 고 대뇌척수로를 통해 아래다리까지 도달한다고 하였다. 이들 연구내용으로 미루어 보아 턱관절과 넙다리뒤근 상호 간에 긍 정적인 영향을 미친 것으로 사료된다.

앞서 언급한 Espejo 등(2016)9)이 제시한 넙다리뒤근의 고 유수용성신경근촉진 중재는 비록 턱관절의 통증이 경감되며 능 동 입벌리기가 증가된다는 등의 연구가 일부 있어왔으나 턱관 절 부위의 직접적인 치료와의 비교를 통한 간접적인 치료의 효 과 정도에 대한 연구는 미비한 실정이라 임상적용을 위한 근거 가 부족하였다. 이와 같은 간접적인 치료의 효과는 턱관절의 통증이 극심하거나 염증, 종양 그리고 부종 등으로 인해 직접 적인 치료의 어려움이 있을 경우 유용하다는 점에서 그 의의가 있기 때문에 본 연구는 능동 입벌리기에 대한 넙다리뒤근 고유 수용성신경근촉진 중재의 임상적용을 위한 근거를 제시하기 위 하여 능동 입벌리기의 직접적인 중재에 해당하는 턱관절 고유 수용성신경근촉진 중재와 간접적인 중재에 해당하는 넙다리뒤 근 고유수용성신경근촉진 중재를 비교하는 연구를 시행하였다. 비록 직접적인 중재에 해당하는 턱관절 고유수용성신경근촉진 중재의 효과가 더 크게 나타났으나 간접적인 중재에 해당하는 넙다리뒤근 고유수용성신경근촉진 중재도 유의한 효과가 있음 을 알 수 있었다. 이러한 결과를 토대로 아직까지는 넙다리뒤 근 고유수용성신경근촉진 중재를 능동 입벌리기의 중재로 임상 에서 적용하기에는 더 많은 연구가 필요하지만 다른 부위의 중 재를 통해 간접적인 치료 효과를 얻을 수 있다는 점에 그 의의 가 있다고 사료된다.

본 연구의 대상자들은 모두 건강한 성인들로 구성되어 있 어서 연구결과를 환자들을 대상으로 하는 임상에 바로 일반화 시키기에는 어려움이 있을 것이다. 그리고 턱관절과 넙다리뒤 근 고유수용성신경근촉진 중재의 즉각적인 효과만을 보았기에 앞으로의 연구에서는 더 많은 피험자를 대상으로 혹은 턱관절 장애나 특정 질환을 가진 환자들을 대상으로 장기적인 중재 효 과를 증명할 수 있는 연구가 필요할 것으로 사료된다. 또한 본 연구에서는 한 다리만의 고유수용성신경근촉진 중재를 적용하
였지만 앞으로 두 다리의 고유수용성신경근촉진 중재를 다룬 연구들이 필요하다고 사료된다. Bretischwerdt 등 $(2010)^{24)}$ 의 연구에서는 양쪽의 넙다리뒤근 고유수용성신경근촉진 중재 시 우세쪽의 넙다리뒤근 고유수용성신경근촉진 중재보다 능동 입 벌리기가 1.75 배 증가하였다. 이처럼 양쪽의 넙다리뒤근 고유 수용성신경근촉진 중재가 능동 입벌리기에 직접적인 중재만큼 의 효과가 있다면 큰 의의가 있을 것으로 보이며 향후 이와 관 련된 연구들이 필요할 것으로 생각된다.

\section{V. 결 론}

본 연구는 건강한 성인 남녀 17 명을 대상으로 턱관절 고유수 용성신경근촉진 중재와 넙다리뒤근 고유수용성신경근촉진 중재 시 앞으로 숙이기, 오금 각 그리고 능동 입벌리기에 미치는 영 향을 알아보았다. 연구결과 턱관절 고유수용성신경근촉진 중재 시 앞으로 숙이기, 오금 각 그리고 능동 입벌리기 검사에서 유 의한 변화가 있었고, 넙다리뒤근 고유수용성신경근촉진 중재에 서도 앞으로 숙이기, 오금 각 그리고 능동 입벌리기 검사에서 유의한 변화가 있었다. 두 중재를 비교한 결과 앞으로 숙이기 검사에서는 서로 간의 유의한 차이는 없었다. 오금 각 검사에 서는 넙다리뒤근 고유수용성신경근촉진 중재군이 더 유의하게 증가하였고, 능동 입벌리기 검사에서는 턱관절 고유수용성신경 근촉진 중재군이 더 유의하게 증가하였다.

이러한 결과를 토대로 비록 능동 입벌리기에 있어서 간접적인 중 재에 해당하는 넙다리뒤근 고유수용성신경근촉진 중재가 직접적인 중 재에 해당하는 턱관절 고유수용성신경근촉진 중재만큼의 효과는 아니 지만 다른 부위의 중재를 통해서 간접적인 치료 효과를 얻을 수 있다 는 점에 그 의의가 있다고 사료된다.

\section{References}

1. Kim JS, Kim DE, Jung DH, et al. a review of recent studies for treatment of tmd using cnki database. Journal of Korean Medicine Rehabilitation. 2016;26(2) :61-74.

2. Cho MS, Kim CS, Cheon SH. Association between self-esteem and temporomandibular disorder in the high school students. Journal of Korean society of Dental Hygiene. 2016;16(1):111-20.

3. Zhang Y, Montoya L, Ebrahim S, et al. Hypnosis/ Relaxation therapy for temporomandibular disorders: a systematic review and meta-analysis of randomized controlled trials. 2015: 29(2):115-25.

4. Kim MW, Kim MJ, Kim JS, et al. The relationship between stomatognathic habit and temporomandibular joint dysfunction. The Korean Academy of Physical Therapy 
Science. 2000;7(1):295-310.

5. Ko MY, Kim IH, Ok SJ, et al. Prognosis of recurred TMD patients according to conservative therapy. J Oral Med Pain. 2007;32(2):241-50.

6. Chang DH, Bae UY, Lee IS, et al. two clinical case studies on temporomandibular disorder with upper cervical manipulation. The Journal of Korea CHUNA Manual Medicine for Spine and Nerves. 2011;6(2):45-52.

7. Jung DW, Chung AY, Kim ST. Management of temporomandibular disorder. Journal of Dental Rehabilitation and Applied Science. 2012;28(4):441-52.

8. McNeely ML, Olivo SA, Magee DJ. A systematic review of the effectiveness of physical therapy interventions for temporomandibular disorders. Phys Ther. 2006;86(5): 710-25.

9. Espejo-Antúnez L, Castro-Valenzuela E, Ribeiro F, et al. Immediate effects of hamstring stretching alone or combined with ischemic compression of the masseter muscle on hamstrings extensibility, active mouth opening and pain in athletes with temporomandibular dysfunction. Journal of Bodywork and Movement Therapies. 2016;20(3):579-87.

10. Bumann A, Lotzmann U, Mah J. TMJ disorders and orofacial pain: the role of dentistry in a multidisciplinary diagnostic approach. 1st. Thieme Medical Publishers. 2002;303-7.

11. Friedman MH, Weisberg J. Joint play movements of the temporomandibular joint:Clinical considerations. Arch Phys Med Rehabil. 1984;65(7):413-17.

12. Rocabado M. Physical therapy for the postsurgical TMJ patient. J Craniomandibular Diso. 1989;3(2):75-82.

13. Israel HA, Syrop SB. The important role of motion in the rehabilitation of patients with mandibular hypomobility: a review of the literature. J Craniomandibular Prac. 1997;15(1):74-83.

14. Oh DW, Kim KS, Lee GW. Physical therapy on temporomandibular joint dysfunction. Phys Ther Kor. 2000;7(1):101-20.

15. Sharman MJ, Cresswell AG, Riek S. Proprioceptive neuromuscular facilitation stretching. Spor Medic. 2006;36(11):929-39.

16. Lee GP, Ng GY. Effects of stretching and heat treatment on hamstring extensibility in children with severe mental retardation and hypertonia. Clin Rehabil. 2008;22(9): 771-9.
17. Kalamir A, Bonello R, Graham P, et al, Pollard H. Intraoral myofascial therapy for chronic myogenous temporomandibular disorder: a randomized controlled trial. J Manip Phys Ther. 2012;35(1):26-37.

18. Freitas SR, Vilarinho D, Rocha Vaz J, et al. Responses to static stretching are dependent on stretch intensity and duration. Clin Phys Funct Imag. 2015;35(6):478-84.

19. Lim KI, Nam HC, Jung KS. Effects on hamstring muscle extensibility, muscle activity, and balance of different stretching techniques. J Phys Ther Sci. 2014;26(2): 209-13.

20. Jang WS. Comparison of kinesio taping and hold relax technique on hamstring flexibility in short track players. J Korea Spor Resea. 2013;24(4):53-62.

21. Youdas JW, Haeflinger KM, Kreun MK, et al. The efficacy of two modified proprioceptive neuromuscular facilitation stretching techniques in subjects with reduced hamstring muscle length. Phys Theor Pract. 2010;26(4):2 40-50.

22. Gray D. The relative effectiveness of proprioceptive neuromuscular facilitation versus ultrasound therapy in the treatment of temporamandibular joint dysfunction caused by masticatory myofascial trigger points, in terms of subjective and objective clinical findings 2002.

23. Fernández-de-las-Peñas $C$, Carratalá-Tejada $M$, LunaOliva L, et al. The immediate effect of hamstring muscle stretching in subjects' trigger points in the masseter muscle. J Muscul Pain. 2010;14(3):27-35.

24. Bretischwerdt C, Rivas-Cano L, Palomeque-del-Cerro $\mathrm{L}$, et al. Immediate effects of hamstring muscle stretching on pressure pain sensitivity and active mouth opening in healthy subjects. J Manip Phys Ther. 2010;33(1):42-7.

25. Ibanez-Garcia J, Alburquerque-Sendin F, RodriguezBlanco $\mathrm{C}$, et al. Changes in masseter muscle trigger points following strain-counterstrain or neuro-muscular technique. J Bodyw Mov Ther. 2009;13(1):2-10.

26. Oliveira-Campelo NM, Rubens-Rebelatto J, Marti NVFJ, et al. The immediate effects of atlanto-occipital joint manipulation and suboccipital muscle inhibition technique on active mouth opening and pressure pain sensitivity over latent myofascial trigger points in the masticatory muscles. J Orthop Sports Phys Ther. 2010;40(5):310-7

27. Taylor D, Fryer G, McLaughlin P. The effect of cervical spine isometric contract-relax technique on hamstring 
extensibility. Australas Chiropr Osteopathy. 2003;11(1): 21-6.

28. Cho SH, Kim SH, Park DJ. The comparison of the immediate effects of application of the suboccipital muscle inhibition and self-myofascial release techniques in the suboccipital region on short hamstring. J Phys Ther Sci. 2015;27(1):195-7.

29. Pollard H, Ward G. A study of two stretching techniques for improving hip flexion range of motion. J Manip Phys Ther. 1997;20(7):443-7. 